\title{
HUBUNGAN ANTARA SELF-EFFICACY DENGAN KECEMASAN KOMUNIKASI INTERPERSONAL PADA MAHASISWA BARU
}

\author{
Nur Fitriyana, Diah Karmiyati, Muhammad Salis Yuniardi, Didik \\ Widiantoro
}

Program Studi Psikologi Islam, Fakultas Studi Islam

Universitas Muhammadiyah Riau

nurfitriyana@umri.ac.id

\begin{abstract}
Communication is important in carrying out every activity. Especially in lecturing activities for students. Students who have just entered experience a lot of adaptation processes. One of them is the adaptation of communication that is different from the previous environment. There are different abilities students have in dealing with this environment. This study aims to find out whether there is a relationship between self-efficacy and interpersonal communication anxiety in new students. The number of subjects of this study were 314 people from the Ministry of Health Palu Health Polytechnic students, which were divided into 3 majors namely; 100 midwifery academics, 120 nursing academics, and 94 environmental health. In this study using a proportional random sampling technique. By using (1) self-efficacy scale, and (2) interpersonal communication anxiety scale. Data management uses Pearson Product Moment correlation analysis, with the SPSS 18 for Mac computer program. From this study the results obtained correlation coefficient $(r)=(-0.572)$, showed that there was a significant relationship between self-efficacy and interpersonal communication anxiety in new students of the Palu Health Ministry of Health. The higher the selfefficacy of new students, the lower the anxiety of interpersonal communication. Conversely, the lower the self-efficacy, the higher the anxiety of interpersonal communication in new students.
\end{abstract}

Keywords: self-efficacy, interpersonal communication anxiety, and students

\begin{abstract}
ABSTRAK
Komunikasi merupakan hal yang penting dalam melakukan setiap aktifitas. Terutama pada kegiatan perkuliahan pada mahasiswa. Mahasiswa yang baru masuk banyak mengalami proses adaptasi. Salah satunya adalah adaptasi komunikasi yang berbeda dari lingkungan sebelumnya. Terdapat kemampuan yang berbeda-beda mahasiswa miliki dalam menghadapi lingkungan tersebut. Penelitian ini memiliki tujuan untuk memperoleh apakah adanya hubungan antara self-efficacy terhadap kecemasan komunikasi interpersonal pada mahasiswa baru. Adapun jumlah dari subjek penelitian ini sebanyak 314 orang dari mahasiswa Poltekes Kemenkes Palu, yang terbagi atas 3 jurusan yaitu ; akedemik kebidanan 100 orang, akedemik keperawatan 120 orang, dan kesehatan lingkungan 94 orang. Pada penelitian ini menggunakan teknik sample proportional random sampling. Dengan menggunakan (1) Skala self-efficacy, dan (2) Skala kecemasan komunikasi interpersonal. Pengelolaan data menggunakan analisis korelasi Pearson Product Moment, dengan program komputer SPSS 18 for Mac. Dari penelitian ini diperoleh hasil nilai koefisien korelasi $(\mathrm{r})=(-0,572)$, menunjukkan ada hubungan yang signifikan antara self-efficacy dengan kecemasan komunikasi interpersonal pada mahasiswa baru Poltekes Kemenkes Palu. Semakin tinggi selfefficacy yang dimiliki oleh mahasiswa baru maka semakin rendah kecemasan komunikasi interpersonal. Sebaliknya, semakin rendah self-efficacy maka semakin tinggi kecemasan komunikasi interpersonal pada mahasiswa baru.
\end{abstract}

Kata kunci: self-efficacy, kecemasan komunikasi interpersonal, dan mahasiswa 


\section{PENDAHULUAN}

Dalam berkomunikasi mencakup pada seluruh aspek kehidupan. Kemampuan setiap individu dalam berkomunikasi secara efektif sangat diperlukan dalam komunikasi. Terutama untuk bakal penerus bangsa ialah mahasiswa. Mahasiswa adalah salah satu kelompok masyarakat yang memiliki status ikatan perguruan tinggi. Masa perkuliahan berbeda dengan proses belajar mengajar ketika duduk di bangku sekolah, dimana pada masa perkuliahan mahasiswa dalam proses belajar mengajarnya dituntut untuk mampu aktif berperan dengan mandiri seperti mencari berbagai informasi mengenai kuliah.

Komunikasi juga memiliki peran penting dalam interaksi sosial. Dalam kenyataannya, manusia tidak bisa hidup sendiri. Hal tersebut memiliki arti dalam menjalani kehidupannya pasti memiliki ketergantungan dengan orang lain. Dalam hal itu, interaksi antara manusia sangat penting ada dan tidak akan pernah hilang. Kemampuan dalam berkomunikasi menjadi hal yang penting dalam proses interaksi sosial. Karena dalam menjalin hubungan baik harus dengan baik menyampaikan komunikai. Baik itu dalam bentuk langsung maupun tidak langsung.

Manusia merupakan salah satu dari ciptaan Tuhan yang sempurna dibanding dengan makhluk ciptaan yang lainnya. Terdapat perbedaan dari manusia yakni pada struktur dan fungsi yang baik dimilikinya. Manusia merupakan mahluk yang berbagai macam dimensi serta memiliki akal dan pikiran serta mampu melakukan interaksi sosial. Manusia merupakan ciptaan yang dalam kehidupannya ditakdirkan untuk bersosial dan tidak dapat hidup sendiri, baik itu secara fisik dan sosial secara kuat, sehingga setiap manusia membutuhkan pertukaran informasi.

Hal ini sesuai dengan hakikat yang ada bahwa adanya beberapa mahasiswa yang tidak mampu dalam mengembangkan pola komunikasi dengan orang lain (komunikasi interpersonal formal ataupun informal). Permasalahan saat ini terdapat kekeliruan yang ditanggapi oleh setiap mahasiswa. Salah satunya adalah masalah komunikasi, dalam konteks pembelajaran di kelas setiap mahasiswa berasal dari berbagai daerah. Hal ini menunjukan terdapatnya perbedaan gaya komunikasi yang dimiliki oleh setiap individu mahasiswa. Secara tidak sadar mereka memiliki tingkat kecemasan yang bervariasi dalam memulai setiap pembicaraan yang berkaitan dengan akademik maupun di luar akademik. Hal ini disampaikan oleh 
Suranto (2011) bahwa komunikasi dapat dikatakan efektif apabila pesan diterima dan dimengerti sebagaimana dimaksud oleh pengirim pesan, pesan ditindaklanjuti dengan sebuah perbuatan secara suka rela oleh penerima pesan, pesan juga dapat diterima berdasarkan gaya komunikasi yang dimiliki oleh setiap pembicaraan.

Dalam kehidupan sehari-hari, sering ditemui permasalah dalam berkomunkasi. Hal tersebut tertuang dalam hasil wawancara dengan Subjek E mahasiswa UMM Malang, yang mengatakan bahwa dia sangat sulit dalam memulai pembicaraan dengan orang lain. Jadi ia cenderung untuk diam dan menunggu. Hal ini dialaminya pada teman baru. Akan tetapi hal tersebut juga ia alami dengan dosen-dosennya. Ia cenderung takut dalam menyampaikan pendapat dalam perkuliahan.

Hardjana (2011) menyampaikan bahwa proses berkomunikasi yang efektif merupakan sebagai sebuah pesan yang dapat diserap oleh penerima dengan baik. Kemudian pesan tersebut dilanjutkan dengan respon berupa perilaku oleh penerima pesan. Sehingga menjadi kekuatan bagi individu tersebut.

Penelitian dari Negara Amerika menunjukkan 10 sampai 20 mahasiswa Amerika menderita aprehensi komunikasi (Hunt, Scott, McCroskey, 1978;148). Indvidu yang mengalami kecemasan saat berkomunikasi berusaha untuk melakukan komunikasi seminimal mungkin. Hal memungkinan terjadinya masalah dalam berkomunikasi interpersonal salah satu penyebabnya adalah terdapatnya kecemasan yang meliputi ketakutan saat memperoleh respon atau penyampaian yang kurang baik dari penerima pesan atau orang lain.

Penelitian yang dilakukan oleh Riani (2014), hubungan antara self-efficacy dengan kecemasan saat presentasi pada mahasiswa, dapat diketahui bahwa ada hubungan yang negatif yang signifikan antara self-efficacy dengan kecemasan saat presentasi pada mahasiswa, hal ini diketahui dari koefisien korelasi (r) sebesar -0.589 dengan signifikan $0,000(\mathrm{p}<0,05)$ artinya ada hubungan negative yang signifikan pada self-efficacy dengan kecemasan saat presentasi pada Mahasiswa Universitas Esa Unggul.

Pada kemampuan berkomunikasi interpersonal ditemukan adanya gangguan komunikasi yang disebut dengan communication apprehension, yaitu munculnya sebuah respon perilaku negatif yang berbentuk kecemasan yang seseorang alami 
pada saat berkomunikasi (Rakhmat, 2008). Dalam cemas berkomunikasi merupakan keadaan yang tidak jelas kapan munculnya sehingga individu tersebut dengan tiba-tiba merasa gemetaran, ketakutan, mengeluarkan keringat dan kehilangan kata-kata untuk berbicara dengan teman baru, dosen dan orang sekitarnya. Dalam penelitian yang dilakukan oleh Rini (2013) tentang hubungan antara self-efficacy dengan kecemasan menghadapi ujian nasional, dengan hasil menunjukan bahwa ada hubungan negatif yang sifnifikan dengan nilai $(\mathrm{r}=-0.615$, $\mathrm{p}=0,000)$. Artinya semakin tinggi self-efficacy siswa ujian nasional, maka semakin rendah kecemasan yang dihadapi oleh siswa tersebut, dan begitupun sebaliknya.

Self-efficacy merupakan penilaian seseorang bagaimana mampu melakukan pendekatan dengan berbagai saran, tugas, dan tantangan. Orang yang memiliki selfefficacy akan berupaya untuk menangani keadaan yang mengancam sehingga tidak menimbulkan rasa cemas dan tidak mudah terusik dengan keadaan yang mengancam dirinya. Begitu pula sebaliknya, jika seseorang yang self-efficacynya rendah ia akan kurang mampu mengurangi situasi yang dapat membahayakan maka dari itu akan mengalami suatu kecemasan. Dari penjelasan di atas, penulis memiliki urgensi atau keinginan untuk melakukan penelitian mengenai masalah self-efficacy dengan kecemasan komunikasi interpersonal.

Berdasarkan teori di atas, peneliti memiliki ketertarikan untuk melihat teori dalam kehidupan nyata, yang nantinya dalam diterapkan pada mahasiswa baru. Oleh sebab itu peneliti akan melakukan penelitian mengenai adanya hubungan antara self-efficacy dan kecemasan komunikasi interpersonal pada mahasiswa baru.

\section{Self Efficacy}

Bandura (dalam Pajares, 2002) mendefinisikan self-efficacy sebuah perasaan individu yang mana individu pandai dan dapat melakukan tindakantindakan yang tepat. Oleh sebab itu, dapat ditarik kesimpulan bahwa suatu kepercayaan diri merupakan makna yang terkandung dari keyakitan individu itu untuk mengatur dan memunculkan tindakan yang dibutuhkan ketika berhadapan dengan keadaan khusus yang mungkin tidak jelas, sulit untuk diprediksi, dan penuh tekanan. 
Bandura (dalam Alwisol, 2008:287) mengemukakan bahwa self-efficacy yaitu suatu penilaian diri yang dapat memberikan pilihan tindakan sehingga muncul tindakan yang baik atau buruk dari individu dan hal ini dilakukan sesuai dengan isyarat yang diberikan. Self-efficacy menggambarkan penilaian kemampuan diri.

Sedangkan Baron \& Byrne mendefinisikan (2003:183) self-efficacy merupakan keyakinan individu dalam kemampuannya untuk mengerjakan tugas yang diberikan, supaya mencapainya dan dapat mengatasi hambatan yang diperolehnya.

\section{Kecemasan Komunikasi Interpersonal}

Kecemasan (anxiety), merupakan suatu perasan yang memiliki sifat umum, yakni individu yang merasakan kehilangan atau ketakukan kepercayaan diri yang tidak jelas wujudnya. Hal ini diungkapkan oleh Freud (dalam Wiramihardja, 2005:67).

May (2010:53) mengartikan kecemasan adalah kondisi subjektif seseorang ketika mampu menyadari bahwa dirinya telah dihancurkan. Kecemasan juga disebut sebagai ancaman terhadap nilai-nilai penting.

Manual of Mental Disorder (1994:393) menjelaskan bahwa kecemasan diartikan sebagai antisipasi kepekaan pada indera terhadap bahaya atau ketidak beruntungan dimasa depan yang diiringi dengan perasaan tidak menyenangkan atau adanya ketegangan dalam gejala-gejala fisik. Fokus bahaya yang diantisipasi tersebut dapat bersifat eksternal maupun internal.

Menurut Chaplin (2000:32) kecemasan adalah ketakutan dan kekhawatiran mengenai masa-masa yang akan datang tanpa ada sebab khusus yang memunculkan ketakutan tersebut. Kecemasan adalah emosi yang tidak menyenangkan yang ditandai dengan istilah-istilah seperti kekhawatiran dan rasa takut yang terkadangdialami dalam tingkat yang berbeda.

Kecemasan adalah suatu sinyal yang memberi suatu peringatan akan adanya bahaya yang mengancam dan memungkinkan seseorang mengambil tindakan untuk mengatasi ancaman (Kaplan, Sadock, Grebb, 1997:3). Jika kecemasan hanya sebagai suatu sinyal peringatan, kecemasan dapat dianggap sebagai suatu emosi yang sama seperti ketakutan. Kecemasan memperingatkan adanya ancaman 
eksternal dan internal, dan memiliki kualitas menyelamatkan hidup. Pada tingkat yang lebih rendah, kecemasan memperingatkan ancaman cedera pada tubuh, rasa takut, keputusan, kemungkinan hukuman, atau frustasi dari kebutuhan sosial. Kecemasan akan mengarahkan seseorang untuk mengambil langkah yang diperlukan untuk mencegah ancaman atau meringankan akibatnya (Kaplan, Sadock, Grebb, 1997:4).

\section{METODE PENELITIAN}

Adapun menggunakan metode analisis ini dengan teknik analisis korelasi Product Moment. Yaitu mengetahui hubungan Self-Eficacy dengan Kecemasan Komunikasi. Seluruh proses perhitungan dilakukan dengan perhitungan analisis dengan menggunakan SPSS 18.00 for Mac.

Penelitian ini menggunakan Teknik sample Purposive Random Sampling. Pengambilan purposive sampling merupakan teknik pengambilan data dengan sampel tertentu (Sugiono, 2010. Kriteria subjek dalam penelitian ini adalah mahasiswa yang berasal dari luar daerah berstatus resmi sebagai Mahasiswa baru di POLTEKES Kemenkes Palu, yakni angkatan 2011/2012. Mahasiswa tersebut terdiri dari wanita dan pria, dari ketiga jurusan yang ada di POLTEKES Kemenkes Palu.

Pupulasi penelitian ini adalah mahasiswa baru di Kemenkes Palu berjumlah 314 orang, yang terbagi atas 3 jurusan yaitu ; Akedemik kebidanan 100 orang, akedemik keperawatan 120 orang, dan Kesehatan lingkungan 94 orang. Sampel adalah sebagian dari populasi (Azwar, 2010:79). Dalam penelitian ini sampel yang dipilih hanya 110 orang dari ketiga jurusan tersebut. yang masing-masing diwakili oleh 35 orang dari jurusan Akademik kebidanan, 42 orang dari Akademik keperawatan dan 33 orang dari Kesehatan lingkungan.

\section{HASIL DAN PEMBAHASAN}

\section{Uji Validitas}

Pengujian validitas dilakukan oleh angka yang disebut koefisien validitas atau biasa disebut dengan koefisien korelasi product moment. Korelasi product 
moment digunakan untuk menggambarkan hubungan antara dua buah variabel yang sama-sama berjenis interval atau rasio (Winarsusnu, 2002:72).

Rumus untuk mencari koefisen korelasi product moment dapat menggunakan angka kasar (Winarsunu, 2002:74), seperti di bawah ini:

$$
r=\frac{N \cdot \sum X Y-\left(\sum X\right) \cdot\left(\sum Y\right)}{\sqrt{N \cdot \sum X^{2}-\left(\sum X\right)^{2}} \cdot \sqrt{N \cdot \sum Y^{2}-\left(\sum Y\right)^{2}}}
$$

Keterangan :

$$
\begin{array}{ll}
\mathrm{r}_{\mathrm{xy}} & \text { : Koefisien Korelasi Product Moment } \\
\mathrm{X} & \text { : nilai butir (skor item) } \\
\mathrm{Y} & \text { : nilai subyek (skor total) } \\
\mathrm{N} & \text { : Jumlah sampel }
\end{array}
$$

Untuk mengukur koefisen korelasi product moment, peneliti menggunakan aplikasi program SPSS. 16. Pedoman untuk menentukan validitas item adalah dengan membandingkan antara $r$ hasil $\left(\mathrm{r}_{0}\right)$ dengan $\mathrm{r}$ tabel $\left(\mathrm{r}_{\mathrm{t}}\right)$. jika dalam perhitungan

\begin{tabular}{|c|c|c|c|c|}
\hline No & Aspek & $\begin{array}{l}\text { No Item } \\
\text { Valid }\end{array}$ & $\begin{array}{c}\text { Indek } \\
\text { Validitas }\end{array}$ & $\begin{array}{l}\text { Nomor Item } \\
\text { Tidak Valid }\end{array}$ \\
\hline 1 & $\begin{array}{l}\text { Kepercayaan diri pada } \\
\text { situasi yang tidak } \\
\text { menentu yang } \\
\text { mengandung kekaburan } \\
\text { dan penuh tekanan. }\end{array}$ & $\begin{array}{c}1,2,3,4,5 \\
21,22,23 \\
24,25\end{array}$ & $0,351-0,707$ & - \\
\hline 2 & $\begin{array}{c}\text { Keyakinan akan } \\
\text { kemampuan dalam } \\
\text { mengatasi masalah atau } \\
\text { tantangan. }\end{array}$ & $\begin{array}{c}6,7,8,9,10 \\
26,27,28 \\
29,30\end{array}$ & $0,409-0,748$ & - \\
\hline 3 & $\begin{array}{l}\text { Keyakinan akan mencapai } \\
\text { target yang ditetapkan. }\end{array}$ & $\begin{array}{c}11,12,13, \\
14,15,31, \\
32,33,34,35\end{array}$ & $0,486-0,778$ & - \\
\hline
\end{tabular}
data diperoleh hasil $r_{0}>r_{t}$ maka item dinyatakan valid. Sebaliknya, jika $r_{0}, r_{t}$ maka item tersebut tidak valid atau gugur.

Tabel 1

\section{Uji Validitas Skala Self-Efficacy}




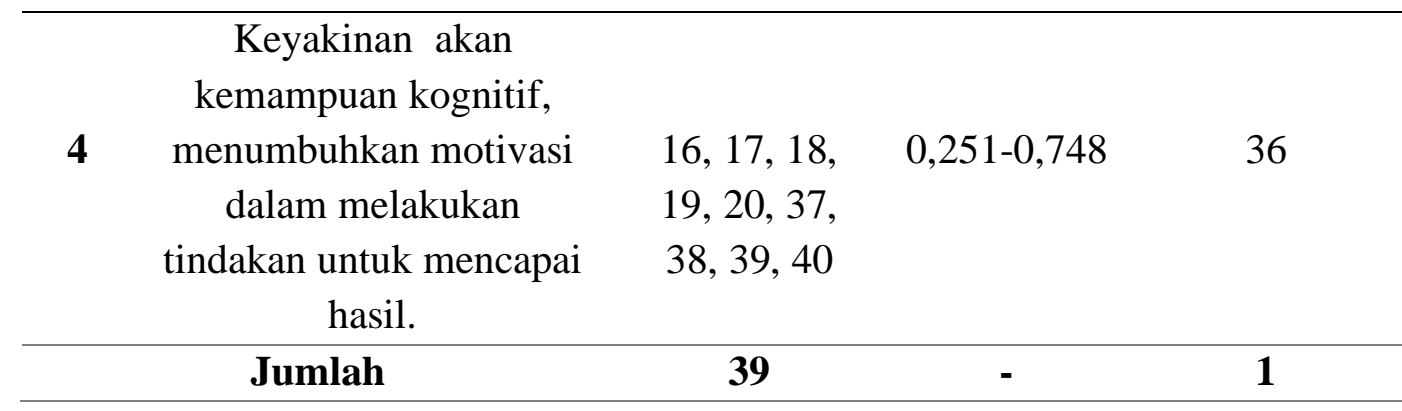

Berdasarkan hasil uji validitas terhadap skala self-efficacy yang berjumlah 40 item, diperoleh 39 item valid dan 1 item tidak valid.

Tabel 2

Uji Validitas Skala Kecemasan Komunikasi Interpersonal

\begin{tabular}{|c|c|c|c|c|}
\hline No & Aspek & No Item Valid & $\begin{array}{c}\text { Indek } \\
\text { Validitas }\end{array}$ & $\begin{array}{l}\text { Nomor Item } \\
\text { Tidak Valid }\end{array}$ \\
\hline 1 & Komponen somatis & $\begin{array}{c}2,3,4,5,6,25 \\
26,27,28,29,30\end{array}$ & $0,201-0,803$ & 1 \\
\hline 2 & Komponen perilaku & $\begin{array}{c}7,8,9,10,11,12, \\
31,32,33,34,35, \\
36\end{array}$ & $0,511-0,796$ & - \\
\hline 3 & Komponen emosi & $\begin{array}{c}13,14,15,16,17 \\
18,37,38,39,40 \\
41,42\end{array}$ & $0,444-0,779$ & - \\
\hline 4 & Komponen kognitf & $\begin{array}{c}19,20,21,22,23 \\
24,43,46,47\end{array}$ & $0,225-0,775$ & 44,45 \\
\hline & Jumlah & 45 & - & 3 \\
\hline
\end{tabular}

Berdasarkan hasil uji validitas terhadap kecemasan komunikasi interpersonal yang berjumlah 48 item, diperoleh 45 item valid dan 3 item tidak valid.

\section{Uji Reliabilitas}

Untuk melaksanakan uji reliabilitas instrumen dikerjakan dengan menggunakan program komputer SPSS versi 16.0 for windows. Dimana dari hasil perhitungan, jika diperoleh koefisien tiap-tiap faktor memiliki alpha $(\alpha)$ lebih besar daripada norma alpha standar yaitu 0,6 yaitu dikatakan reliabel (Azwar, 2010). 


\section{Tabel 3}

Uji Reliabilitas Skala Self-Efficacy

\begin{tabular}{|c|c|c|c|}
\hline No & Aspek & Alpha & Status \\
\hline 1 & $\begin{array}{l}\text { Kepercayaan diri pada situasi yang tidak menentu } \\
\text { yang mengandung kekaburan dan penuh tekanan. }\end{array}$ & 0,728 & Reliabel \\
\hline 2 & $\begin{array}{c}\text { keyakinan akan kemampuan dalam mengatasi } \\
\text { masalah atau tantangan. }\end{array}$ & 0,774 & Reliabel \\
\hline 3 & Keyakinan akan mencapai target yang ditetapkan. & 0,820 & Reliabel \\
\hline 4 & $\begin{array}{l}\text { Keyakinan akan kemampuan kognitif, } \\
\text { menumbuhkan motivasi dalam melakukan } \\
\text { tindakan untuk mencapai hasil. }\end{array}$ & 0,737 & Reliabel \\
\hline
\end{tabular}

Tabel 4

Uji Reliabilitas Skala Kecemasan Komunikasi Interpersonal

\begin{tabular}{clcc}
\hline No & \multicolumn{1}{c}{ Aspek } & Alpha & Status \\
\hline $\mathbf{1}$ & Komponen somatis & 0,829 & Reliabel \\
\hline $\mathbf{2}$ & Komponen perilaku & 0,850 & Reliabel \\
\hline $\mathbf{3}$ & Komponen emosi & 0,867 & Reliabel \\
\hline $\mathbf{4}$ & Komponen kognitf & 0,805 & Reliabel \\
\hline
\end{tabular}

\section{Paparan Hasil}

Berdasarkan hasil analisa data yang didapatkan dimana nilai probabilitas kesalahan $(p)=0,0000$ menunjukkan bahwa hasil uji statistik yang dilakukan sangat signifikan atau bermakna yang berarti tidak hanya pada sampelnya saja, tetapi juga bisa digeneralisasikan pada populasinya. Sedangkan nilai koefisien korelasi $(\mathrm{r})=(-0,572)$ menandakan adanya hubungan yang berarah negatif antara kedua variabel. Hal ini berarti apabila nilai pada self-efficacy mengalami kenaikan, maka akan diikuti juga turunnya nilai pada kecemasan komunikasi interpersonal, sebaliknya jika nilai pada selff-efficacy mangalami penurunan, maka akan diikuti dengan dengan naiknya nilai pada kecemasan komunikasi interpersonal. Dari hasil penelitian juga ditemukan koefisien determinasi $\left(r^{2}\right)$ sebesar $32,7 \%\left(r^{2}=0,327\right)$. Hal ini menunjukan bahwa sumbangan efektif self-efficacy dengan kecemasan 
komunikasi interpersonal sebesar 32,7 \%. Adapun sisanya sebesar 67,3\% dipengaruhi oleh variabel lain yang tidak diteliti dalam penelitian ini.

Tabel 5

Rangkuman Analisis Korelasi antara Self-Efficacy dengan Kecemasan Interpersonal

\begin{tabular}{cc}
\hline Analisis & Indeks Analisis \\
\hline Koefisien korelasi $(\mathbf{r})$ & $-0,572$ \\
\hline Koefisien Determinasi $\left(\mathbf{r}^{\mathbf{2}}\right)$ & 0,327 \\
\hline Probabilitas Kesalahan $(\mathbf{p})$ & 0,0000 \\
\hline
\end{tabular}

\section{Pembahasan}

Berdasarkan dari hasil penelitian pada tabel 5 terdapat nilai koefisien korelasi $(r)=(-0,572)$ yang menandakan adanya hubungan yang berarah negatif antara kedua variable. Hal ini berarti masih banyak mahasiswa baru di POLTEKES yang memiliki self-efficacy yang rendah. Ini menunjukan bahwa mahasiswa baru di POLTEKES Kemenkes Palu juga masih banyak yang ragu atas kemampuan dirinya untuk membentuk suatu komitmen pada tujuan pribadinya. Situasi atau tugas yang sulit merupakan suatu hal yang mengancam, sehingga dalam pola pikir mereka lebih banyak megarah kepada hal yag lemah dan kurang yang tidak mampu mencapai hal baik yang berdampak terjadinya sebuah kecemasan komunikasi interpersonal.

Terdapat beberapa mahasiswa yang memiliki self-efficacy yang cukup tinggi memandang kesulitan tidak sebagai ancaman tetapi sebagai tantangan yang harus ia hadapi. Adanya sebuah tujuan yang jelas dan komitmen yang kuat menjadikan individu terfokus pada usaha yang konsisten untuk mencapainya. Jika individu mempunyai pengalaman kegagalan, maka kegagalan tersebut akan dipandang sebagai pembelajaran dan akan menjadi acuan untuk memotivasi menjadi diri yang lebih baik. Sebaliknya jika individu mengalami sebuah pengalaman dalam keberhasilan, maka individu akan memperkuat keyakinan dirinya dalam menghadapi sebuah situasi. 
Sebaliknya diperoleh hasil data dari mahasiswa baru cukup rendah (selfefficacy) yang mereka miliki, individu akan cenderung menghindar dalam menghadapi situasi yang mengancam. Keragu-raguan atas kemampuan dirinya membangun komitmen yang rendah terhadap tujuan pribadi. Situasi atau tugas yang sulit merupakan sebuah hal yang mengancam, sehingga pikiran mereka lebih tertuju pada kelemahan dan kekurangan yang tidak dapat dilakukan untuk mencapai hal yang positif. Kegagalan akan disikapi dengan perasaan putus asa sehingga tidak percaya diri untuk melakukannya kembali. Hal ini akan memicu sebuah kecemasan dan perasaan tertekan yang akibatnya akan mempengaruhi kekondisi fisiknya.

Bandura (dalam Nevid, Spencer, Greene, 2005:183) menyampaikan jika manusia tidak percaya dengan keahliannya dalam menjawab setiap tantangan yang hadir makan mereka akan timbul perasaan yang cemas apabila manusia itu dihadapi oleh tantangan tersebut, dan juga sebaliknya jika individu yakin dengan yang ia miliki dalam menghadapi tantangan maka individu tersebut tidak akan mengalami kecemasan. Hal inilah yang sering terjadi pada mahasiswa baru.

Mahasiswa baru yang memiliki self-efficacy yang tinggi memandang kesulitan sebagai tantangan yang harus ia hadapi, bukan sebagai ancaman untuk dihindari. Adanya sebuah tujuan yang jelas dan komitmen yang kuat menjadikan individu terfokus pada usaha yang konsisten untuk mencapainya. Jika individu mempunyai pengalaman kegagalan, maka kegagalan tersebut akan dipandang sebagai pembelajaran dan akan menjadi acuan untuk memotivasi menjadi diri yang lebih baik. Sebaliknya jika individu mengalamai sebuah pengalaman dalam keberhasilan, maka individu akan memperkuat keyakinana dirinya dalam menghadapi sebuah situasi.

Sebaliknya beda halnya dengan mahasiswa baru yang memiliki self-efficacy yang rendah, individu akan cenderung menghindar dalam menghadapi situasi yang mengancam. Keragu-raguan atas kemampuan dirinya membentuk komitmen yang rendah terhadap tujuan pribadi. Situasi atau tugas yang sulit merupakan sebuah hal yang mengancam, sehingga pikiran mereka lebih tertuju pada kelemahan dan kekurangan yang tidak dapat dilakukan untuk mencapai hal yang positif. Kegagalan akan disikapi dengan perasaan putus asa sehingga tidak percaya diri untuk 
melakukannya kembali. Hal ini akan memicu sebuah kecemasan dan perasaan tertekan yang akibatnya akan mempengaruhi kekondisi fisiknya.

Perbedaan self-efficacy inilah yang akan menentukan keberhasilan mahasiswa baru dalam menghadapi sebuah komunikasi interpersonal. hal tersebut sesuai dengan yang dikemukakan oleh Bandura (1997) bahwa self-efficacy diri akan mempengaruhi beberapa aspek dari kognisi dan perilaku seseorang, sehingga perilaku individu akan berbeda dengan individu lainnya. individu yang memiliki self-efficacy yang tinggi maka tingkat kecemasan komunikasi interpersonalnya semakin rendah karena saat individu merasa cemas yang muncul pada saat ia harus berkomunikasi interpersonal dapat diatasi dan dikelola bahkan dapat dijadikan pendorong usahanya untuk mendapatkan isyarat tentang situasi komunikasi tersebut, sehingga individu dapat berkomunikasi interpersonal dengan baik dan efektif. Selain itu karena merasa yakin dengan kemampuaannya individu yang memiliki self-efficacy tinggi akan berusaha lebih keras dan bertahan lebih lama dalam menghadapi kesulitan-kesulitan atau hambatan-hambatan yang mungkin muncul.

Ketika self-efficacy dimiliki pada seseorang itu rendah maka dapat menimbulkan tingkat kecemasan komunikasi interpersonalnya semakin tinggi. Kecemasan komunikasi interpersonal ini, dapat menurunkan keinginan mahasiswa baru untuk melakukan sebuah komunikasi dengan orang lain, dosen, teman, dan orang yang berada disekitarnya. Kecemasan ini dapat ditandai dengan perilaku menghindar ketika telibat dalam suatu interaksi dengan dosen, teman, dan orangorang disekelilingnya, hal ini juga terlihat dalam perubahan pada kondisi fisik seperti, jantung menjadi kuat dan keringat dingin, serta dalam perubahan emosi individu akan tampak gelisah dan mudah tersinggung.

Individu dengan self-efficacy yang tinggi akan mampu mengendalikan situasi yang berbahaya sehingga tidak merasa cemas dan tidak merasa terusik oleh situasi mengancam tersebut. Begitu pula sebaliknya, jika seseorang yang memiliki self-efficacy yang rendah, maka seseorang kurang mampu mengontrol situasi yang menjadi ancaman dan akan mengalami suatu kecemasan.

Kecemasan suatu kondisi psikologis yang pasti dialami oleh seluruh manusia. Begitu juga dengan mahasiswa yang baru saja menduduki sebuah tingkat 
perguruan tinggi, mahasiswa baru seringkali cemas untuk memulai pembicaraan atau berkomunikasi dengan orang baru mereka kenal. Hal ini tentu saja akan berpengaruh terhadap proses perkuliahan mahasiswa tersebut, seperti kurangnya teman di lingkungan kampus, sulit berkomunikasi, bahkan mungkin saja akan mempengaruhi hasil akademik mereka.

Rasa cemas ini sering muncul ketika mahasiswa saling berkenalan dengan sesama mahasiswa baru, senior, dan dosen. Bahkan ketika proses belajar mengajar di kelas, rasa cemas sering muncul ketika diminta untuk tampil persentasi depan kelas, diskusi kelompok, dan sebagainya. Maka apabila hal ini terus-menerus terjadi tentu saja akan berpengaruh terhadap proses perkuliahan mahasiswa tersebut, seperti kurangnya teman di lingkungan kampus, sulit berkomunikasi, bahkan mungkin saja akan mempengaruhi hasil akademik mereka.

Akan tetapi, dalam perbadaan antara individu mengenai self-efficacy yang memiliki taraf rendah, individu tersebut akan menghindar dari kondisi yang mengancam dirinya. Keragu-raguan atas kemampuan dirinya membangun keyakinan yang rendah pada tujuan pribadi. Kondisi yang sangat berat menjadikan suatu hal yang dapat menjadi ancaman, sehingga dalam pikiran mereka lebih mengarah kepada suatu kelemahan yang tidak mampu diselesaikan. Kegagalan akan disikapi dengan perasaan putus asa sehingga tidak percaya diri untuk melakukannya kembali. Hal ini akan memicu sebuah kecemasan dan perasaan tertekan yang akibatnya akan mempengaruhi ke kondisi fisiknya.

Kenyataanya dalam sebuah komunikasi interpersonal terdapat hambatanhambatan dalam berkomunikasi, yang disebut dengan istilah communication aprehension, yaitu dimana seseorang mengalami suatu keadaan yang tidak nyaman, dalam menghadapi situasi berkomunikasi dengan orang lain atau kelompok yang ditandai dengan adanya ciri-ciri kecemasan. Cemas interpersonal ini disebabkan karena kurangnya kepercayaan diri ketika menghadapi sebuah situasi komunikasi interpersonal. Untuk mengatasi hal tersebut diperlukan adanya self-efficacy yang tinggi untuk mengurangi rasa kecemasan yang dihadapi oleh idividu. Karena selfefficacy mampu mempengaruhi individu dan menentukan keberhasilan dalam menghadapi sebuah komunikasi interpersonal tersebut. Semakin tinggi self-efficacy mahasiswa baru, maka akan semakin rendah tingkat kecemasan komunikasi 
interpersonal dan akan menganggap dirinya mampu mengatasi situasi yang mengancam, begitu pula sebaliknya, mahasiswa baru yang memiliki self-efficacy yang rendah akan memiliki kecemasan komunikasi interpersonal yang tinggi, karena merasa tidak mampu mengatasi situasi yang mengancam.

\section{KESIMPULAN}

Berdasarkan hasil analisa penelitian yang telah dilakukan, maka dapat diperoleh nilai koefisien $(r)=(-0,572)$, koefisen determinasi $(r 2)=0,327$ dan probabilitas kesalahan $(\mathrm{p})=0,000$. Hal ini menunjukkan adanya hubungan negatif yang signifikan antara self-efficacy dengan kecemasan komunikasi interpersonal pada mahasiswa baru POLTEKES Kemenkes Palu. Hal ini membuktikan, Semakin tinggi self-efficacy maka semakin rendah kecemasan komunikasi interpersonal pada mahasiswa baru. Sebaliknya, semakin rendah self-efficacy maka semakin tinggi kecemasan komunikasi interpersonal pada mahasiswa baru. Adapun sumbangan efektif self-efficacy terhadap kecemasan komunikasi interpersonal sebesar 32,7\%, sisanya (100\%-32,7\%) sebesar 67,3\% dipengngaruhi oleh variable lain, yang tidak diteliti oleh peneliti.

\section{DAFTAR PUSTAKA}

Alwisol. (2004). Psikologi kepribadian. Malang: UMM press.

Atkinson, R. L. (2002). Pengantar Psikologi. Interaksara.

Azwar, D. S. (2010). Metode penelitian. Yogyakarta: Pustaka pelajar.

, D. S. (2010). Metode penelitian. Yogyakarta: Pustaka pelajar.

, D. S. (2010). Penyusunan skala psikologi. Yogyakarta: Pustaka pelajar.

D. S. (2010). Reliabilitas dan validitas. Yogyakarta: Pustaka pelajar.

Bandura, A. (1997). Self efficacy:the exercise of control. New york: W.H Freeman and company.

Bani. (2010). Hubungan antara self efficacy dengan kecemasan menghadapi mutasi pada aparat kepolisian. Skripsi . Universitas Muhammadiyah Malang.

Baron, R. A., \& Byrne, D. (2003). Psikologi sosial (10 ed.). (W. C. Kristiaji, R. Medya, Penyunt., \& R. Djuwita, Penerj.) Jakarta: Erlangga. 
Chaplin, J. P. (2004). Kamus lengkap psikologi. Jakarta: Raja grafindo persada.

Daradjat, Z. (1996). Kesehatan mental. Jakarta: Gunung agung.

Feist, J., \& Feist, G. (2010). Teori Kepribadian. Jakarta: Selemba Humanika.

Kaplan, H., Sadock, B., \& Grebb, J. (1997). Sinopsis Psikiatri. New York: Binapura Aksara.

Karlinger, F. N. (2004). Asas-asas penelitian behavioristik (3 ed.). Yogyakarta: Gajah mada university press.

Kartono, K. (1998). Patologi sosial 2. Jakarta: Rajawali.

Maramis, W. F. (1990). Ilmu kedokteran jiwa. Surabaya: Airlangga university press.

Nevid, J., Rathus, S., \& Greene, B. (2003). Psikologi Abnormal. Jakarta: Erlangga.

Nolen, S., \& Hoeksema. (2001). Abnormal Psychology. New York: McGrawwHill.

Pajares. (t.thn.). Overview of social cognitive theory and of self-efficacy. Dipetik Desember 9, 2011, dari http://www.emory.edu/Education/mfp/eff.html.

Rahmania. (2010). Hubungan antara self efficacy dengan kecemasan mengajar pada guru RSBI di SMA Muhammadiyah 2 Sidoarjo. Skripsi . Universitas Muhammadiyah Malang.

Rakhmat, J. (2009). Psikologi Komunikasi. Bandung: PT Remaja Rosdakarya.

Riani, W. S., \& Rozali, Y. A. (2014). Hubungan antara self efficacy dan kecemasan saat presentasi pada mahasiswa univeristas esa unggul. Jurnal Psikologi Esa Unggul, 12(01), 126836.

Rini, H. P. (2013). Self Efficacy Dengan Kecemasan Dalam Menghadapi Ujian Nasional. Cognicia, 1(1).

Sarwono, Jonathan. (2006). Analisis Data Penelitian. Jokjakarta : Andi Jokjakarta.

Suranto. (2011). Komunikasi Interpersonal. Yogyakarta: Graha Ilmu.

Suryabrata, S. (1998). Metodologi penelitian. Jakarta: Raja grafindo persada.

West, R., \& Turner, L. H. (2008). Pengantar Teori Komunikasi. Jakarta: Selemba Humanika. 
Wahyuni, E. (2015). Hubungan self-effecacy dan keterampilan komunikasi dengan kecemasan berbicara di depan umum. Jurnal Komunikasi Islam, 5(1), 5182.

Winarsunu, T. (2002). Statistik dalam penelitian psikologi \& pendidikan. Malang: UMM Press.

Wiramihardja, S. (2007). Pengantar Psikologi Abnormal. Bandung: PT Refika Aditama.

Yusuf, S. (2007). Teori kepribadian . Bandung: Remaja rosdakarya. 